\section{Journal of Anatolian Environmental and Animal Sciences (Anadolu Çevre ve Hayvancllık Bilimleri Dergisi) Doi: https://doi.org/10.35229/jaes.526426}

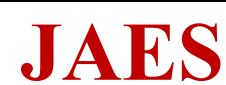

Year: 4, No: 1, $2019(16-21)$

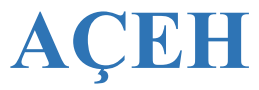

Yıl: 4, Sayı:1, $2019(16-21)$

\title{
Laktik Asit Bakterilerinden Kısmi Saflaştırılan Bakteriyosinlerin Aktivitesi Üzerine pH, Sıcaklık, Kimyasal Maddelerin Etkisi [*]
}

\section{Hatice Aysun MERCIMEK TAKCI ${ }^{1 *}$ Kıvılcım ÇAKTU GÜLER ${ }^{2}$ Melis SÜMENGEN ÖZDENEFE ${ }^{3}$ Ayșenur ÖZŞAVL $\dot{I}^{1}$ Gülcihan GÜZELDAĞ $\breve{G}^{4}$}

\author{
${ }^{1}$ Kilis 7 Aralık Üniversitesi, Fen-Edebiyat Fakültesi, Moleküler Biyoloji ve Genetik Bölümü, Kilis, Türkiye. \\ (D: https://orcid.org/0000-0002-3388-1153, D: https://orcid.org/0000-0003-2042-0021 \\ ${ }^{2}$ Hacettepe Üniveristesi, Fen-Edebiyat Fakültesi, Biyoloji Bölümü, Ankara, Türkiye. (1): https://orcid.org/0000-0002-3096-1246 \\ ${ }^{3}$ Yakın Doğu Üniversitesi, Mühendislik Fakültesi, Biyomedikal Mühendisliği Bölümü, Lefkoşa, KKTC. D: https://orcid.org/0000-0003-0804-9557 \\ ${ }^{4}$ Cukurova Üniversitesi, Fen-Edebiyat Fakültesi, Biyoloji Bölümü, Adana, Türkiye. (D: https://orcid.org/0000-0001-9352-6308
}

Atıf yapmak için: Mercimek Takcı, H.A., Çaktu Güler, K., Sümengen Özdenefe, M., Özşavli, A. \& Güzeldağ, G. (2019). Laktik asit bakterilerinden kısmi saflaştıılan bakteriyosinlerin aktivitesi üzerine $\mathrm{pH}$, sıcaklık, kimyasal maddelerin etkisi. Anadolu Çev. ve Hay. Dergisi, 4(1), 16-21. Doi: https://doi.org/10.35229/jaes.526426

How to cite: Mercimek Takcı, H.A., Çaktu Güler, K., Sümengen Özdenefe, M., Özşavli, A. \& Güzeldağ, G. (2019). Effect of pH, temperature and chemical substances on the activity of bacteriocins partially purified by lactic acid bacteria. J. Anatolian Env. and Anim. Sciences, 4(1), 16-21. Doi: https://doi.org/10.35229/jaes.526426

Öz: Bakteriler tarafından üretilen ribozomal antimikrobiyal peptidlerin bir çeşidi olan bakteriyosinler, bakterilerin \%99'undan fazlası tarafından üretilmektedir. Üretici bakteri ile yakın ilişikli veya ilişkisiz bakteriyel suşların gelişimini inhibe eden bakteriyosinler, insan vücudu için zararsızdır. Patojen bakterilere karşı antibiyotiklere kıyasla yaygın olarak kullanılmaktadır. Ancak gıda güvenlik uyugulamaları ve gıda korumada potansiyel antimikrobiyal ajan olarak değerlendirilmektedir. Bu nedenle çalışmamızda Kilis yöresel peynirinden izole edilen laktik asit bakterilerinin bakteriyosin üretim kapasitesi araştırılmıştır. Bacillus cereus, Vankomisin-Dirençli Enterococci (VRE) ve Staphylococcus aureus'a karşı antibakteriyel aktiviteli hücre bağımlı bakteriyosin üreten 3 adet laktik asit bakterisi izole edilmiştir. Bakteriyosin süspansiyonlarının en etkili olduğu test bakterisi B. cereus'tur. Süspansiyonların test bakterileri üzerinde geniş bir $\mathrm{pH}$ aralığında (pH 4-12) aktivite gösterdiği belirlenmiş olup, $40^{\circ} \mathrm{C}$ sıcaklıkta inhibitör etkinin stabilitesini koruduğu gözlenmiştir. Çeşitli kimyasal maddeler ile ön inkübasyonu takiben P2 süspansiyonunun diğer süspansiyonlara karşın aktivitesini sürdürdügü belirlenmiştir.

Anahtar sözcükler: Bakteriyosin, gıda koruma, laktik asit bakterileri

\section{Effect of pH, Temperature and Chemical Substances on the Activity of Bacteriocins Partially Purified by Lactic Acid Bacteria}

Abstract: Bacteriocins, one kind of ribosomal antimicrobial peptides, are produced by more than $99 \%$ of bacteria. Bacteriocins that are inhibited the growth of bacterial strains closely related or unrelated with producer bacteria, is harmless for human body (Yang vd., 2014). It is not extensively used against pathogenic bacteria in comparison with antibiotics. But, it is evaluated as potential antimicrobial agent in food preservation or food safety applications. In this study, the capability of bacteriocin production of lactic acid bacteria isolated from Kilis local cheese was investigated. 3 lactic acid bacteria producing bacteriocin showed antimicrobial activity against Bacillus cereus, Vancomycinresistant Enterococci (VRE) and Staphylococcus aureus were isolated. All bacteriocin suspensions were effective against B. cereus. And bacteriocin suspensions were active a wide range of $\mathrm{pH}$ values $(\mathrm{pH} 4-12)$ and stable to $40^{\circ} \mathrm{C}$ heat. Following pre-incubation with the various chemical substances, the activity of $\mathrm{P} 2$ suspension was determined to preserve in comparison with other bacteriocin suspensions. 


\section{GíRiș}

Uzun raf ömrüne, güzel tat ve kokuya sahip besinlerin hazırlanması ve tüketiciye sunulması gıda endüstrisinin en temel işlevlerindendir. Gıdaların fiziksel, kimyasal ve mikrobiyolojik olarak uzun süre dayanıklılığa sahip olması için gıdalara çeşitli katkı maddeleri eklenmektedir. Bu katkı maddelerinin insan sağlığına karşı kanserojen ve toksik etkiye sahip olma gibi olumsuz özelliklerinin keşfi, gıda kalitesinin arttırılması konusunda doğal ürünlere olan ilginin artmasına neden olmuştur (Kurt \& Zorba, 2005).

Katkısız ve doğal gıda ürünlere olan talep, biyokoruma yöntemiyle hazırlanan gıdaların tüketimine hız vermiştir. Günümüzde gıda endüstrisinde en çok tercih edilen biyokoruma yöntemlerinden birisi laktik asit bakterilerinin (LAB) fermantasyon ürünleridir. Homofermentatif ve heterofermantatif LAB'leri; hidrojen peroksit, organik asitler, antimikrobiyal enzimler, alkol, diasetil, hidrojen sülfür, reuterin, karbondioksit ve bakteriyosinler gibi metabolitlerden birini veya birkaçını sentezlemektedir. Bu metabolitler etki mekanizmalarına bağlı olarak patojenler üzerinde statik ve/veya sidal etkiye sahiptir. Özellikle gida patojenleri üzerinde antimikrobiyal aktivite göstermektedirler. (Yang \& Clausen, 2004; Rossland vd., 2005; Yang vd., 2014).

LAB'lerinin fermente ürünlerinden biri olan bakteriyosinlerin gıda üretiminde kullanılması peynir üretimi kadar eskiye dayanmaktadır (Akkoç vd., 2009). Bakteriyosinler ilk kez 1925 yılında Gratia tarafindan E.coli S'e karşı gözlenen inhibisyon ile keşfedilmiştir. Kolisin olarak adlandırılan bu bakteriyosinin aktivitesi, duyarlı hücrelerin yüzeyindeki özel proteinlerin varlığına bağlı olduğu 1946 yılında Frederic tarafından ifade edilmiştir (Güllüce vd., 2013). Yeni Zellenda'da 1933 yılında protein yapılı bir antimikrobiyal madde tanımlandı ve 1947 yılında bu bakteriyosin nisin olarak adlandırılmıştır. İngiltere'de ilk kez 1953 y1lında pazarlanan nisin o zamandan beri 48'den fazla ülkede kullanılması için onaylanmıştır. Bakteriyosinlerin gıda endüstrisinde kullanımı için 1969 yılında büyük bir adım atılmış ve Ortak Gıda ve Tarım Örgütü/Dünya Sağlık Örgütü Gıda Katkı Maddeleri Uzman Komitesi tarafından gıdalarda kullanımı güvenli olarak değerlendirilmiştir. Avrupa'da 1983 yılında gıda katkı maddesi listesine E234 numarası ile eklenmiş ve 1988'de pastörize edilmiş peynir çeşitlerinde kullanılması ABD Gıda ve İlaç Ajansı (FDA) tarafindan onaylanmıştır (Cotter vd., 2005; Parada vd., 2007).

Gıdalarda sağladığı antimikrobiyal etki sayesinde kimyasal hatta çoğu zaman zararlı sayılan katkı maddelerinin yerini alan bakteriyosinler, gram pozitif ve gram negatif bakteriler tarafından üretilmektedir. Protein yapıdaki bakteriyosinler gıdalar ile insan vücuduna alındığında, proteazlarla kolaylıkla sindirilebilmektedir (Yang vd., 2014). $\mathrm{Bu}$ önemli ayrıcalığının yanı sıra tatsız, kokusuz, renksiz olmaları ve aynı zamanda da pH ve sicaklık toleransına sahip olmaları kullanım alanlarını da arttırmıştır (Kurt \& Zorba 2005; Seçkin, 2010; Güllüce vd., 2013). Bakteriyosinlerin nispeten geniş antimikrobiyal spekturuma sahip olmaları ve gıda kaynaklı bozulmalara karşı dirençli yapısı gıda endüstrisinde kullanılma nedenleri arasında gelmektedir (Güllüce vd., 2013). Hayvan yemlerinde de antibiyotik yerine bakteriyosinlerin kullanımının, hem enfeksiyonların durdurulmasını sağladığı hem de hayvanlarda çoklu ilaç direncinin gelişmesini engellediği gözlenmiştir (Üstündağ \& Özdoğan, 2011; Yang vd., 2014). Bazı araştırmacılar kanser tedavisinde de bakteriyosinlerin tümör hücrelerine karşı aktivite gösterdiğini belirtmişlerdir (Yang vd., 2014).

$\mathrm{Bu}$ çalışmanın amacı, Kilis yöresinden elde edilen geleneksel üretilmiş beyaz peynirlerden laktik asit bakterilerinin izolasyonu ve bu bakterilerden antimikrobiyal aktiviteye sahip bakteriyosinlerin üretimi ve gida endüstrisinde kullanılabilirliğinin araştırılmasıdır.

\section{MATERYAL ve METOT}

Laktik Asit Bakterilerinin İolasyonu: Kilis bölgesinde geleneksel yöntemlerle üretilmiş beyaz peynir örnekleri laktik asit bakterilerini izole etmek için kullanılmıştır. Steril fizyolojik tuzlu (\%0.9 $\mathrm{NaCl})$ dilüsyonlarından $\left(10^{-3}, 10^{-5}\right.$ ve $\left.10^{-7}\right) 100 \mu \mathrm{L}$ örnek Neutral Red Chalk Lactose Agar'a (NRCLA: et peptonu $3.00 \mathrm{~g} / \mathrm{L}$; et özütü $3.00 \mathrm{~g} / \mathrm{L}$; maya özütü $3.00 \mathrm{~g} / \mathrm{L}$; laktoz $10.00 \mathrm{~g} / \mathrm{L}$; kalsiyum karbonat $15.00 \mathrm{~g} / \mathrm{L}$; nötral kırmızısı $0.05 \mathrm{~g} / \mathrm{L}$; agar agar $15.00 \mathrm{~g} / \mathrm{L} ; \mathrm{pH}$ 6.8 \pm 0.2 ) inoküle edilmiştir. GasPak anaerobik sistem kullanılarak plaklar $30^{\circ} \mathrm{C}^{\prime} \mathrm{de}$ inkübe edilmiştir (Ogunbanwo vd., 2003).

Bakteriyosin Üreten LAB'ların Seçimi: Nutirent agar plaklarında geliştirilen bakterilerin, bakteriyosin üretip üretmediklerinin belirlenebilmesi için seçilen izolatlar Mueller-Hinton (MHA) agar plaklarına nokta şeklinde inoküle edilerek 24 saat $30^{\circ} \mathrm{C}^{\prime} \mathrm{de}$ inkübe edilmiştir. İnkübasyonu takiben Luria Bertani (LB) buyyonda 24 saat geliştirilen test bakteri kültürlerinin (Bacillus cereus, Vankomisin-Dirençli Enterococci (VRE) ve Staphylococcus aureus) $100 \mu \mathrm{L}$ 'si \%0.7 agar içeren $5 \mathrm{~mL}$ 'lik LB buyyona aktarılmıştır. Karışım Mueller Hinton plaklar üzerine dökülerek $37^{\circ} \mathrm{C}$ 'de $24-48$ saat inkübe edilmiştir. İnkübasyon süresi sonunda etrafında test bakterilerinin üremediği şeffaf zonlar görülen laktik asit bakterileri seçilerek stoklanmıştır (van Belkum vd., 1989). LAB'lar Nutrient agar içeren eğik katı şeklinde hazırlanmış besi ortamlarında karakterizasyon çalışmalarında kullanılmak üzere $+4^{\circ} \mathrm{C}$ 'de buzdolabında muhafaza edilmiştir.

Bakteriyosinin Kısmi Saflaştırılması: Kültürler santrifüj $\left(5500 \mathrm{rpm} 60\right.$ dak $\left.+4^{\circ} \mathrm{C}\right)$ edilerek hücreler uzaklaştırılmıştır. Süpernatantın pH değeri $\mathrm{NaOH}$ ile 7'ye ayarlanmıştır. \%50 oranında amonyum sülfat eklenerek $4^{\circ} \mathrm{C}^{\prime}$ de 24 saat karıştırılmıştır. Karışım aynı koşullarda santrifuj edildikten sonra pelletler toplanarak $25 \mathrm{~mL}(\mathrm{pH} 7)$ $0.05 \mathrm{M}$ potasyum fosfat tamponunda süspanse edilmiştir. 15 $\mathrm{mL}$ metanol/kloroform (1:2 v/v) karışımı ilave edilerek $4^{\circ} \mathrm{C}$ 'de 1 saat inkübe edilmiştir. Kısmi saflaştırılmış bakteriyosin süspansiyonu aktivite testlerinde kullanılmıştır (Moreno vd., 2003). 
Bakteriyosin Aktivite Testi: Nutrient Broth (NB) buyyonda geliştirilmiş kültürlerin $100 \mu \mathrm{L}$ 'si 4 mL \%0.6 agar içeren yumuşak nutrient agar ile karıştırılarak daha önceden hazırlanan MHA plaklarına inkübe edilmiştir. Yarı katı agar donduktan sonra kaba bakteriyosin süspansiyonun $10 \mu \mathrm{L}$ 'si inoküle edilmiştir. $37^{\circ} \mathrm{C}$ 'de $24-48$ saatlik inkübasyon sonrası bakteriyosinlere yönelik $2 \mathrm{~mm}$ ve daha fazla şeffaf zon çapları pozitif sonuç olarak değerlendirilmiştir (Ivanova vd., 2000).

Bakteriyosin Aktivitesi Üzerine, Sicaklık, pH, Kimyasal Maddelerinin Etkisinin Araştırılması:

Isıl İşlemin Etkisi: Kaba bakteriyosinin 1S1 stabilitesini belirlemek amaciyla bakteriyosin örneğinin 100 $\mu \mathrm{L}$ 'si $40,50,60,70$ ve $80^{\circ} \mathrm{C}$ 'de 15 dak bekletilerek oda sicaklığına soğutulduktan sonra bakteriyosin örneklerinin antimikrobiyal aktiviteleri belirlenmiştir (Ivanova vd., 2000; Sarika vd., 2010).

Kimyasal Maddelerin Etkisi: $\mathrm{Bu}$ amaçla, $10 \mu \mathrm{L}$ bakteriyosin $10 \mu \mathrm{L}$ organik çözücüyle (formaldehit, kloroform, aseton, metanol, etanol, hekzan ve etil eter) eppendorf tüpte karıştırılarak oda sicaklığında 1-4 saat bekletilmiştir. Farklı organik çözücülere maruz bırakılan bakteriyosin örneği ile aktivite testi yapılmıştır (Ivanova vd, 2000; Sarika vd, 2010). Bakteriyosin süspansiyonuna SDS ve Triton X-100 deterjanları \%1, 5.0 mM konsantrasyonda EDTA ilave edilerek $37^{\circ} \mathrm{C}$ ' de 5 saat inkübe edilmiştir. Ve bu sürenin sonunda bakteriyosin örneklerinin antimikrobiyal aktiviteleri belirlenmiştir (Ivanova vd., 2000; Sarika vd., 2010).

pH Etkisi: Kaba bakteriyosin solüsyonu, 1N'lik $\mathrm{NaOH}$ ve 5 M'lık fosforik asit kullanılarak son hacimler eşit olacak şekilde pH'ları 4'den 12'ye kadar ayarlanarak oda sıcaklığında 2 saat bekletildikten sonra örneklerin pH's1 7'ye ayarlanıp aktiviteleri belirlenmiştir (Ivanova vd., 2000; Sarika vd., 2010).

\section{BULGULAR ve TARTIŞMA}

Yöresel beyaz peynir örneklerinden Neutral Red Chalk Lactose Agar (NRCLA) besi ortamında inokülasyonu takiben kolonilerinin etrafında şeffaf zonlar gözlenen suşlar laktik asit bakterileri olarak belirlenmiştir (Şekil 1).

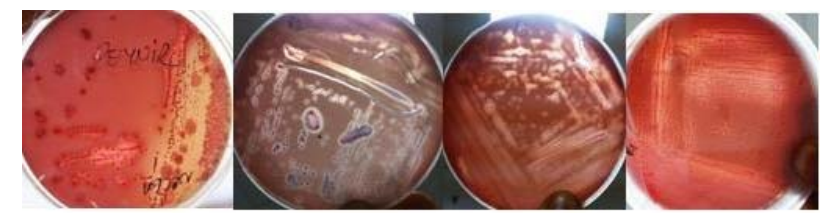

Şekil 1. Peynirden izole edilen laktik asit bakterilerinin NRCLA agardaki karakteristik davranışı

$\mathrm{Bu}$ karakteristik özelliği gösteren sadece 3 adet bakteri kolonisi seçilmiştir. P2, P3 ve P4 olarak isimlendirilen bu suşların gram davranışı ve biyokimyasal aktiviteleri temel alınarak tiplendirilmiştir (Tablo 1).
Tablo 1. Laktik asit bakterilerinin biyokimyasal testlerle tanımlanması.

\begin{tabular}{lccc}
\hline \multirow{2}{*}{ Biyokimyasal testler } & \multicolumn{3}{c}{ Mikroorganizma } \\
\cline { 2 - 4 } & P2 & P2 & P2 \\
\hline Gr davranış1 & + & + & + \\
Morfolojisi & Kok & Kok & Kok \\
Katalaz & - & - & - \\
$30^{\circ} \mathrm{C}$ 'de gelişme & + & + & + \\
$\% 6.5 \mathrm{NaCl}$ ve $30^{\circ} \mathrm{C}$ 'de gelişme & - & - & - \\
$\% 4 \mathrm{NaCl}$ ve $30^{\circ} \mathrm{C}$ 'de gelişme & - & - & - \\
$\mathrm{pH} 9.630^{\circ} \mathrm{C}$ 'de gelişme & - & - & - \\
$45^{\circ} \mathrm{C} / 40^{\circ} \mathrm{C}$ de gelişme & $-/-$ & $-/-$ & $-/-$ \\
Sitrat fermentasyon & - & - & - \\
Arjinin hidrolizi & - & - & - \\
\hline
\end{tabular}

Peynirden izole edilen P2, P3 ve P4 laktik asit bakterilerinin Tablo 1'de verilen mikroskobik ve biyokimyasal testlerin sonuçlarına göre, gram pozitif laktik asit bakterilerini içeren Lactobacillales takımına ait olduğu söylenebilmektedir. Ancak çalışmamızda devam edilecek moleküler teknikler ile bakterilerin tiplendirilmesine tamamlanacaktır.

P2, P3 ve P4 suşlarındaki hücre bağımlı bakteriyosinlerin test bakterilerine karşı (Bacillus cereus, Vankomisin-Dirençli Enterococci (VRE) ve Staphylococcus aureus) inhibitör aktivitesi "sandwich yöntemi" ile incelenmiştir (Şekil 2).

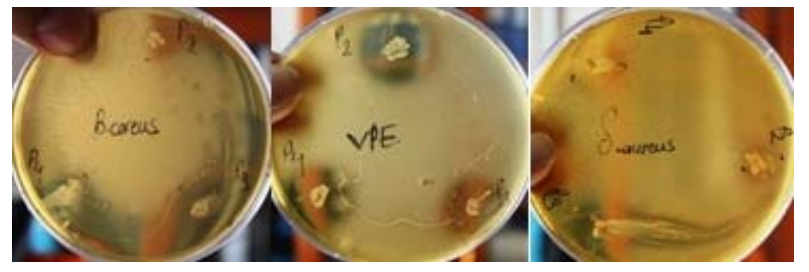

Şekil 2. Hücre bağımlı bakteriyosinlerin test bakterileri üzerinde oluşturduğu inhibitor etkisi

$\mathrm{Bu}$ izolatlar tarafindan üretilen hücre bağımlı bakteriyosinlerin test bakterilerine karşı gösterdiği aktivite, mm cinsinden inhibisyon zon çapı olarak belirlenmiştir (Tablo 2). Diyarel ve emetik olmak üzere iki gıda kaynaklı hastalık tablosu gösteren $B$. cereus için et, süt, pirinç, pudingler, pastalar, sebzeler, balıklar, makarnalar ve peynir riskli gıdalar arasında yer almaktadır. Mide bulantısı, kusma ve sulu diyare ile karakterize edilen $B$. cereus kaynaklı bu hastalıkların çoğu kendiliğinden geçen, kısa süreli ve orta şiddetlidir (İncili vd., 2015). Söz konusu bu bakteriye karşı P2 ve P3 hücre bağıml bakteriyosinlerin 21 ve $20 \mathrm{~mm}$ inhibisyon zonlu antibakteriyel aktivite P4 suşunda gözlenenden daha aktiftir (14 mm).

Tablo 2. Hücre bağımlı bakteriyosinlerin test bakterilerine karşı antimikrobiyal aktivitesi.

\begin{tabular}{lccc}
\hline \multirow{2}{*}{ Test bakterileri } & \multicolumn{3}{c}{ İnhibisyon zon çapları (mm) } \\
\cline { 2 - 4 } & P2 & P2 & P2 \\
\hline B. cereus & 21 & 21 & 21 \\
VRE & 20 & 20 & 20 \\
S. aureus & 19 & 19 & 19 \\
\hline
\end{tabular}

VRE klinik olarak önemli van A tip vankomisin dirençli Enterococcus faecium gibi direnç genlerini içeren 
bakteriyel türlerin çeşitli kombinasyonlarını içermektedir. Gelişim desteği için avoparsin analoğu vankomisinin geniş kullanımı ile çiftlik hayvanları arasında VRE bulunma sıklığı artmaktadır (Nilsson vd., 2012). Bu hayvanlardan elde edilen ve halk sağlığını olumsuz etkileyen gıda ürünleri ile VRE'nin insanlara ulaşması söz konusudur. Gıda kaynaklı hastalıkların yanı sıra beta-laktamlara ve aminoglikozidlere yüksek düzeyde direnç gösteren Vankomisin-dirençli Enterococci hastane kaynaklı enfeksiyonlarda da potansiyel bir firsatçı patojendir. $\mathrm{Bu}$ nedenle çalışmamızda ortalama $20-23 \mathrm{~mm}$ inhibisyon zon çapı aralığında belirlenen antimikrobiyal aktivite ile hücre bağımlı bakteriyosinlerin Vankomisindirençli Enterococci üzerindeki gözlenen inhibitör etkisi önem arz etmektedir.

Gıda pastörizasyonu sırasındaki 1 sıl işlemlere dayanıklı enterotoksin üreten $S$. aureus; et ve süt ürünleri, balık, patates, salata sosları, mayonez, puding ve makarna gibi yiyeceklerde yaygın olarak görülmektedir (Küçükçetin \& Milci, 2007). Ürettiği sitotoksinler ve yoğun antibiyotik direnci sebebi ile 3. dereceden bakteriyemi sebebi olup, pnömoni ve endokardit gibi ciddi hastane enfeksiyonlarına da neden olmaktadır. Bakteriyosin üretici suşlarımızda 13-19 $\mathrm{mm}$ zon çapı ile en düşük inhibitör etki Staphylococcus aureus'a karşı rastlanmış olsa da gözlenen inhibisyon farklı ajanlar ile kombine edilerek geliştirilebilir potansiyele sahiptir.

Kısmi saflaştırılmış bakteriyosin süspansiyonlarının çeşitli kimyasal ve fiziksel ajanlar ile etkileşimi sonucu test bakterileri üzerindeki inhibisyon etkisi Tablo 3,4 ve 5 'te verilmiştir. Sonuçlarımıza göre kısmi saflaştırılmış bakteriyosinlerin inhibitör etkisi, bakteri süspansiyonun elde edildiği laktik asit bakterilerine, ön muamele koşullarına ve test edilen bakteri türlerine göre değişiklik göstermiştir.

Tablo 3. B. cereus üzerinde kısmi saflaştırılan bakteriyosinin $\mathrm{mm}$ cinsinden inhibitör etkisi.

\begin{tabular}{lccc}
\hline Kimyasal Maddeler & \multicolumn{3}{c}{ Bakteriyosin süspansiyonları } \\
\cline { 2 - 4 } & P2 & P3 & P4 \\
\hline Triton X-100 & 11 & 13 & 8 \\
SDS & 12 & 8 & 7 \\
EDTA & 9 & 6 & 3 \\
Formaldehit & $-*$ & $-*$ & $-*$ \\
Aseton & $-*$ & 4 & 7 \\
Kloroform & $-*$ & $-*$ & 3 \\
Metanol & 8 & 6 & $-*$ \\
Etanol & $-*$ & 11 & 9 \\
Hekzan & 3 & $-*$ & $-*$ \\
Etil eter & $-*$ & $-*$ & $-*$ \\
\hline pH & & & \\
\hline pH 4 & $-*$ & $-*$ & $-*$ \\
pH 6 & 5 & 5 & 6 \\
pH 8 & 13 & 10 & 12 \\
pH 10 & 9 & 8 & 8 \\
pH 12 & 11 & 11 & 13 \\
\hline Sicaklık & & & \\
\hline $40^{\circ} \mathrm{C}$ & 11 & 5 & $-*$ \\
$50^{\circ} \mathrm{C}$ & $-*$ & $-*$ & $-*$ \\
$60^{\circ} \mathrm{C}$ & $-*$ & $-*$ & $-*$ \\
$70^{\circ} \mathrm{C}$ & $-*$ & $-*$ & $-*$ \\
$80^{\circ} \mathrm{C}$ & $-*$ & $-*$ & $-*$ \\
\hline$-*$ İnhibisyon zonu gözlenmemistir. & &
\end{tabular}


aynı test bakterisine karşı P3 süspansiyonun inhibisyon aktivitesi $2 \mathrm{~mm}$ olarak gözlenirken, P2 ve P4 süspansiyonu sirasiyla 10 ve $8 \mathrm{~mm}$ 'dir.

Tablo 5. VRE üzerinde kısmi saflaştırılan bakteriyosinin $\mathrm{mm}$ cinsinden inhibitör etkisi

\begin{tabular}{lccc}
\hline Kimyasal Maddeler & \multicolumn{3}{c}{ Bakteriyosin süspansiyonları } \\
\cline { 2 - 4 } & P2 & P3 & P4 \\
\hline Triton X-100 & $-*$ & $-*$ & $-*$ \\
SDS & $-*$ & $-*$ & $-*$ \\
EDTA & $-*$ & $-*$ & $-*$ \\
Formaldehit & $-*$ & $-*$ & $-*$ \\
Aseton & 9 & 7 & 8 \\
Kloroform & $-*$ & $-*$ & $-*$ \\
Metanol & $-*$ & $-*$ & $-*$ \\
Etanol & $-*$ & $-*$ & $-*$ \\
Hekzan & $-*$ & $-*$ & $-*$ \\
Etil eter & $-*$ & $-*$ & $-*$ \\
\hline pH & & & \\
\hline pH 4 & 5 & 4 & 6 \\
pH 6 & 5 & 6 & 4 \\
pH 8 & 5 & 10 & 15 \\
pH 10 & 17 & $-*$ & $-*$ \\
pH 12 & $-*$ & $-*$ & $-*$ \\
\hline Sicaklık & $-*$ & & \\
\hline $40^{\circ} \mathrm{C}$ & & 13 & 12 \\
$50^{\circ} \mathrm{C}$ & 15 & $-*$ & $-*$ \\
$60^{\circ} \mathrm{C}$ & $-*$ & $-*$ & $-*$ \\
$70^{\circ} \mathrm{C}$ & $-*$ & $-*$ & $-*$ \\
$80^{\circ} \mathrm{C}$ & $-*$ & $-*$ & $-*$ \\
\hline$-*$ İnhibisyon zonu gözlenmemiştir & & \\
& $-*$ & & \\
\hline & & & \\
\hline
\end{tabular}

Diğer test bakterilerine kıyasla $B$. cereus'a karş1 bakteriyosin süspansiyonlarını geniş bir $\mathrm{pH}$ aralığında (pH 612) aktivitelerini koruduğu belirlenmiştir. $13 \mathrm{~mm}$ zon çapı ile en yüksek inhibisyon pH'sı 8 ayarlanmış P2 ve pH's1 12'ye ayarlanmış P4 süspansiyonlarında gözlenmiştir. Triton X-100 deterjanı ile ön muamale sonucunda P3 süspansiyonu $13 \mathrm{~mm}$ zon çapı ile en yüksek inhibitör etkiye sahiptir.

pH sonuçlarımızı destekler nitelikte, E. faecium P21 tarafindan üretilen enterosin A ve B'nin $\mathrm{pH}$ 2-11 aralığında; E. faecium JCM 5804T tarafindan üretilen bakteriyosin ise geniş $\mathrm{pH}$ aralığında (pH 2-10) aktivitesini sürdürmüştür (Bilgin, 2008). Bayram ve Yıldırım, (2016) beyaz peynirden elde edilen Enterococcus faecium'dan elde edilen bakteriyosinin de $\mathrm{pH}$ 2-10 aralığında biyolojik aktivitesini sürdürdüğünü belirtmişlerdir.

Deterjanlar (SDS ve Triton X-100) ile ön muamele sonucunda bakteriyosin süspansiyonlarının diğer test bakterilerine karşın en yüksek antibakteriyel aktivitesi $B$. cereus'a karşı ortaya konmuştur. Hekzan ile ön muamele sonucunda sadece P2 süspansiyonun aktivitesini $B$. cereus'a karşı koruduğu belirlenmiştir. Karakterizasyon verilerine dayanarak kısmi saflaştırılmış bakteriyosinlerin en etkili olduğu test bakterisi $B$. cereus'tur.

Ancak bakteriyosinlerin özellikle de nisinin endosporların germinasyonunu engellediği bilgisi (Kurt ve Zorba, 2005) en yüksek inhibitör etkinin B. cereus'a karşı gözlendiğini açıklamaktadır. S. aureus ve B.cereus'a karşı gözlenen sonuçlarımıza benzer şekilde $E$. mundtii ST15'den elde edilen bakteriyosinin Triton X-100, SDS ve EDTA tarafından inaktive olmadığı rapor edilmiştir (Bilgin, 2008).
Konsantrasyona bağlı olarak kimyasal maddelerin etkisinin incelendiği çalışmada ise Bayram ve Yıldırım, (2016) \%25'lik etanol, metanol, etil eter, kloroform, hekzan ve $\% 40$ formaldehit ile ön muamele sonucunda çalışmamızı destekler nitelikte bakteriyosin süspansiyonlarının bazılarının stabilitesini koruduğu ortaya konmuştur.

\section{SONUÇ}

Sonuç olarak hücre bağımlı bakteriyosinlerin kısmi saflaştırılma ve fiziksel/kimyasal ön muameleler sonucunda aktivitelerinin azaldığı gözlenmektedir. Bu sebeple kısmi saflaştırılmış bakteriyosinlerin doğrudan gıda katkı maddesi olarak kullanımına nazaran bakteriyosin sentezleyen P2, P3 ve P4 laktik asit bakterilerinin rekabetçi kültür olarak gıdaya aktarılması ve/veya gıdanın koruyucu ambalaj materyali ile kombine antimikrobiyal biyofilmlerde kullanımı önerilebilmektedir.

\section{TEŞEKKÜR}

$\mathrm{Bu}$ araştırma makalesi Kilis 7 Aralık Üniversitesi Bilimsel Araştırma Projeleri tarafından 2012/1/MAP02 numaralı proje kapsamında desteklenmiştir.

\section{KAYNAKLAR}

Akkoç, N., Şanlıbaba, P. \& Akçelik, M. (2009). Bakteriyosinler: Alternatif gida koruyucuları. Erciyes Üniversitesi Fen Bilimleri Enstitüsü Dergisi, 25(1-2), 59-70.

Bayram, M. \& Yıldırım, Z. (2016). Beyaz peynirden bakteriyosin üreten bakterinin (Enterococcus faecium) izolasyonu ve bakteriyosinin karakterizayonu. Gaziosmanpaşa Bilimsel Araştırma Dergisi, 13, 103-115.

Bilgin, H. (2008). Fermente süt ürününden izole edilen bakteriyosinojenik bir bakterinin antimikrobiyal aktivitesi. Yüksek Lisans Tezi, Gazi Osman Paşa Üniversitesi, Fen Bilimleri Enstitüsü, Tokat, Türkiye.

Cotter, P.D., Hill, C. \& Ross, R.P. (2005). Bacteriocins: Developing Innate Immunity for Food. Microbiology, 3, 777-788.

Güllüce, M., Karadayı, M. \& Barış, Ö. (2013). Bacteriocins: Promising Natural Antimicrobials. Formatex, 1016-1027.

Ivanova, I., Kabadjova, P., Pantev, A., Danova, S. \& Dousset, X. (2000). Detection, Purification and Partial Characterization of A Novel Bacteriocin Substance Produced By Lactoccous lactis Subsp. lactis B14 Isolated From Boza Bulgarian Traditional 
Cereal Beverage. Biocatalysis-2000: Fundamentals \& Applications, 41(6), 47-53.

İncili, G.K., Dikici, A. \& Çalıcıoğlu, M. (2015). Bacillus cereus. Turkiye Klinikleri Food Hygiene and Technology - Special Topics, 1(3), 87-91.

Kurt, Ş. \& Zorba, Ö., (2005). Bakteriyosinler ve Gıdalarda Kullanım Olanakları. YYÜ Vet Fak Derg., 16(1), 7783.

Küçükçetin, A. \& Milci, S. (2008). Staphylococcus aureus ile Kontamine Olan Peynirlerden Kaynaklanan Gida Zehirlenmeleri. Glda, 33(3), 129-135.

Moreno, F.M.R., Callewaert, R., Devreese, B., Van Beeumen, J. \& De Vuyst, L. (2003). Isolation and biochemical characterization of enterocins produced by Enterococci from different sources. J. Appl. Microbiol., 94, 214-229.

Nilsson, O. (2012). Vancomycin resistant enterococci in farm animals occurrence and importance. Infection Ecology and Epidemiology, 2, 1-8.

Ogunbanwo, S.T., Sanni, A.I. \& Onilude, A.A. (2003). Characterization of bacteriocin produced by Lactobacillus plantarum $\mathrm{F} 1$ and Lactobacillus brevis. African Journal of Biotechnology, 2(8), 219227.

Parada, J.L., Carolina, R.C., Adriane, B.P.M. \& Carlos, R.S. (2007). Bacteriocins from Lactic Acid Bacteria: Purification, Properties and use as Biopreservatives. Brazilian Archlves of Biology and Technology, 50(3), 521-542.

Rossland, E., Langsruda, T., Granumb, P.E. \& Sbrhaug, T. (2005). Production of antimicrobial metabolites by strains of Lactobacillus or Lactococcus cocultured with Bacillus cereus in milk. International Journal of Food Microbiology, 98, 193-200.
Sarika, A.R., Lipton, A.P. \& Aishwarya, MS. (2010). Bacteriocin Production by a New Isolate of Lactobacillus rhamnosus GP1 under Different Culture Conditions. Advance Journal of Food Science and Technology, 2(5), 291-297.

Seçkin, A.K., Tosun, H. \& Arıtürk, R. (2010). Biyokorumanın Süt Endüstrisinde Kullanım Olanakları. Gida Teknolojileri Elektronik Dergisi, 5(3), 36-46.

Üstündağ, A.Ö. \& Özdoğan, M. (2011). Kanatlı Hayvan Beslemede Bakteriyosinlerin Kullanım Olanakları. Hayvansal Üretim, 52(2), 69-73.

van Belkum, M.J., Hayema, B.J., Geis, A., Kok, J. \& Venema, G. (1989). Cloning of two bacteriocin genes from a lactococcal bacteriocin plasmid. Appl Environ Microbiol, 55, 1187-1191.

Yang, V.A. \& Clausen, C.A. (2004). Antifungal Metabolites of Lactobacilli. Proceedings from the Woodframe Housing Durability and Disaster Issues Conferences, October 4-6, 2004, Las Vegas, Nevada, USA, 307-311.

Yang, S.J., Lin, C.H., Sung, C.T. \& Fang, J. (2014). Antibacterial Activities of Bacteriocins: Application in Foods and Pharmaceuticals. Frontiers in Microbiology, 5(241), 1-10.

\section{*Corresponding author's:}

Hatice Aysun MERCIMEK TAKCI

Kilis 7 Aralık Üniversitesi, Fen-Edebiyat Fakültesi, Moleküler Biyoloji ve Genetik Bölümü, Kilis, 79000, Türkiye.

E-mail: aysunmercimek@kilis.edu.tr

ORCID: https://orcid.org/0000-0002-3388-1153 